\title{
Public-Private Partnership in Regional Health Care Modernization: Analysis and Strategic Priorities of its Development
}

\author{
Natalia N. Kosinova \\ Volgograd State University \\ Economics and Finance Institute \\ Corporate Finance and Banking Department \\ Volgograd, Russia \\ nnn_05@mail.ru
}

\author{
Sergey P. Sazonov \\ Volgograd State Technical University \\ Economics and Management Faculty \\ Management and Finance of Production Systems and \\ Technological Entrepreneurship Department \\ Volgograd, Russia \\ sazonovsp@mail.ru
}

\author{
Natalia G. Glazkova \\ Volgograd State University \\ International Education Institute \\ Volgograd, Russia \\ Gng 07@inbox.ru
}

\begin{abstract}
For the further development of the Russian economy in the context of global transformation, various forms of a joint venture between state structures and commercial organizations are of great importance. One of the instruments for such interaction is a public-private partnership (PPP), whose main objective is to improve public welfare by combining efforts and resources of the parties, optimally distributing their responsibility and risk.

In the article, we conducted an analysis of PPPs in the healthcare sector as a comprehensive study of positive and negative factors, which may affect the PPPs effective development in health care modernization.

The analysis revealed key strategic priorities of the PPP development in the healthcare sector. Favorable legal, organizational and institutional conditions are required for efficient management of PPP projects implementation in health care modernization in order to increase the level of availability and quality of medical services.
\end{abstract}

Keywords - public-private partnership, concessions, health services outsourcing, investment projects, infrastructure, institutional environment

\section{INTRODUCTION}

Introduction of modern forms of social and economic projects funding is extremely important for the Russian economy, as the traditionally state-owned industries require substantial financial resources. The latter does not always correspond with fiscal positions.

Such industries include education, health care, housing and utilities, transportation and road facilities. Objects related to these areas of economic activity cannot go private due to their social, economic, and strategic importance. Therefore, they cannot be profitable.
Over the past five years, real budget spending on serviceproducing industries has decreased annually by about $10 \%$. In the near future, this trend will likely continue. Meanwhile, the share of attracted private investment is less than $3 \%$ of the total investment in infrastructure development [1].

In the world economic practice organizational forms on the basis of a public-private partnership are created to solve the problem of an economy's strategically important objects underfunding.

The aim of the study is to examine the impact of health PPPs institutional environment on defining the main aspects of PPPs increased efficiency in health care.

\section{MATERIALS AND Methods (MODEL)}

The subjects of the study are economic and financial relations between the state and private businesses within PPP projects in the healthcare sector.

In pursuing the study objective we used the methods of strategic and integrated economic analysis.

When considering the institutional factors impact on the development of PPPs in the healthcare sector, we used a systems approach while analyzing normative legal acts of PPPs in the health care, as well as organizational forms, models, certain PPP instruments in Russian practice.

\section{RESULTS AND DISCUSSION}

A. Analysis of PPPs Implementation Efficiency in Healthcare Sector

At the current stage, systemic reform of the Russian healthcare sector aims at improving the quality of medical services through strategic management of the sector. Despite 
the health care modernization program, which has recently been implemented through additional funding introduction in the form of social security systems, money attraction from medical services consumers, etc., the problems of low economic efficiency of public health care, limited public resources, etc. were not solved. To tackle the issues, PPPs have been used in the world practice.

A rapid development of various forms of PPP in developed economies and, more recently, developing ones, widespread usage of the forms in distinct sectors allows the form of interaction between the state and business to be a characteristic of the modern economy.

The State bears responsibility for ensuring uninterrupted public goods flow. That explains the tendency to preserve a number of sectors and industries in the state ownership. At the same time, private enterprise is mobile, highly resource efficient, innovation-prone.

A set of PPP forms and methods accumulated so far allows while preserving important national state-owned facilities transfer some powers to the private sector. These are features such as construction, operation, and maintenance of productive and social infrastructure, as well as its management.

Public-private partnership in the healthcare sector faces a challenge of making medical care more accessible, and the healthcare resources usage more efficient.

In our opinion, a PPP in the healthcare sector is a mutually beneficial cooperation of central and local authorities, private and non-profit organizations, which helps to ensure effective legal entities of public law task execution in the healthcare sector through attracting private resources for an establishment, reconstruction, management, and maintenance of health services infrastructure [2].

Analysis of the PPP status in the Russian healthcare sector has revealed that, at present, there are more than 70 projects at different stages of implementation, among which 61 projects are already under construction and operation. Within the framework of implemented PPPs in the healthcare sector, it is expected to attract investments of 61 billion rubles, while the total amount of private investment in PPP projects is 57 billion rubles, which is about $10 \%$ of total investment in PPP projects in all sectors [3].

According to the Russian Ministry of Health, 32\% of hospitals и $30 \%$ of clinics require major repairs. They lack hot water supply, piped water, off-grid electricity, and $57 \%$ of equipment is technically and functionally obsolescent. During the modernization program in the following few years, it is necessary to build about 500 hospitals in total. To address strategic challenges the industry needs an investment of $0,8-$ 1,0 trillion rubles. In the healthcare system, up to $20 \%$ of agencies provide services in the areas potentially demanded by private investors, and the plausible amount of investment is 250-270 billion rubles [4].

In addition, "in a number of subjects of the Russian Federation private investments are being attracted into construction and operation of new institutions of public health, such as cancer clinics, rehabilitation centers, dialysis and perinatal centers. There is effective demand for such infrastructure from consumers that can guarantee a return on investment. Experts estimate the investment segment potential for 50-70 billion rubles. In federal public health institutions, the current need for private investment is provisionally estimated at more than 20 billion rubles" [3]. It is a base for a systematic PPP instrumentation usage in order to modernize the healthcare sector and improve availability and quality of medical services.

Thus, our analysis of healthcare PPPs has revealed that in the context of underfunding strategically important areas of an economy in the economic practice of Russia and foreign countries medical institutions are created on the basis on PPP in order to modernize and improve the quality of public services. Aimed at the healthcare sector development, PPP is an effective mechanism for attracting long-term investments.

B. Assessing Institutional Factors Impact on PPPs Development in Healthcare Sector

One of the most important institutional factors, influencing PPPs development in the healthcare sector, is a legal regulation. So, the passage of the Federal law dated July 13, 2015 №224-FZ “On public-private partnerships, municipalprivate partnership in the Russian Federation and amendments in certain legislative acts of the Russian Federation" [5], provides a possibility of creation and/or modernization of medical infrastructure by private investors in order to improve public services quality, allows the status of private ownership on established or renovated infrastructure. An investor has to ensure its use strictly for the authorized purpose.

By law, a public party may participate in a PPP project through direct co-financing, by providing a grant for the project implementation or a state guarantee, as well as take property participation, including land, water, forest areas assignment for an object being created. Apart from that, there is a guarantee mechanism of contract conditions preservation.

An institutional factor, which directly affects PPPs development in the healthcare sector, is the PPP forms and models implementation.

In the generally accepted world practice, there are two forms of cooperation, such as contract and institutional partnerships. Institutional form involves creation of joint ventures between the state and business. Contract form of strategic partnership is a contract on certain functions performance, concerning the object of health care.

Concessions, among existing contract forms of cooperation, are most common in infrastructure industries and social services (including health care), where private investment flows and high-quality management are necessary.

Under a concession, the state is, first and foremost, a public authority. In this capacity, it not only provides partners with some of its power as an owner, but also delegates them some power (exclusive sovereign rights). Rights exclusivity (sovereignty), granted to the concessionaire (private partner) by the state, means that in the framework of the activity, for which he receives the exclusive right, similar activities of any 
third party or the state itself are not allowed. In the Russian economy there is a possibility of life cycle contracts in constriction and reconstruction of health facilities, Russian and foreign private companies attraction into heath facilities management within the concession.

In addition, there are investors who are ready to participate in projects with $8-9 \%$ yield. Abroad many health facilities are built and then managed by large international companies. In this case, private investors provide majority of financial resources for the project, a state is a guarantor of the agreements, including loan repayment or established and operational facilities yield. It allows providing medical care, when there are not enough funds. From an economic standpoint, the benefits are obvious. The state building is 2 times or even more expensive, than a private one. The difference is essential for a health services consumer, too, as he or she can receive them faster and of a better quality.

Thus, when optimizing a PPP system as a whole, and some of its elements, it is vital to take into account the status of institutional environment at both federal level and at the level of distinct federal entities.

\section{Best Regional Practices Analysis of PPP Mechanism Usage in Healthcare Sector}

Among entities, in which the PPP mechanism is used effectively, we can highlight the Republic of Tatarstan. For example, OOO "ABA-Peter" negotiated a concession agreement on the reconstruction of the family planning and reproduction Center for a period of 10 years, allowing the Republic to receive a modern medical institution, which will deal with issues related to reproductive health protection and recovery. OOO "Modern Medicine HD Clinic" concluded 5 concession agreements on establishment and operation of outpatient hemodialysis centers in Kazan, Naberezhnye Chelny, Nizhnekamsk, and Bugulma, thus ensuring the availability of this type of assistance for the Republic's population. In addition, the outpatient hemodialysis Centre in Kazan acknowledged for being the best Russian infrastructure project in the social sphere.

In recent years medical institutes of the country got plentiful modern equipment, but only $20 \%$ of this equipment is fully operational. The reason is that there are not enough trained human resources, leaving many centers without even using allocated state funds for high-tech medical care. That is why a high-level medical technology training center project was established in Kazan in 2008. It was the first PPP training center in the world. Regional authorities provided the building, its capital repair, and administrative support. Business has invested its expertise in project management and took the responsibility of bearing operating expenses. The Center's budget of 15 million dollars was accounted for five years. Here the clinic's doctors, nurses, administrators are trained. Since the Center began operating, over 4000 doctors from 73 cities have already gone through training, for the majority of whom it was free of charge.

There are positive examples of PPPs in other regions, too. In the Samara region on the concession basis, part of extracorporeal blood correction and clinical transfusion Center is under construction. At the end of the project's construction, the private investments volume should be no less than 350 million rubles.

Moscow concluded a concession with ZAO "European Medical Center" on the reconstruction, operation, and organization of four medical centers, such as a positronemission tomography, endovascular surgery, perinatal and rehabilitation support for 49 years.

In the Novosibirsk region under the terms of the concession maternity hospital and dental clinic are being renovated. The maternity hospital will provide high-tech specialized medical care for the treatment of infertility. Annually, 48 residents of the region will be able to obtain aid for free. Up to 300 people may take advantage of a free dental care a year.

Examples of PPP agreements on the basis of regional legislation are the Nephrology Center establishment in the Khabarovsk region (Komsomolsk-on-Amur) and comprehensive medical center construction in Orel. According to the federal subjects of Russia, the implementation of another 29 projects was internally constrained by the lack of legislation in the field of PPP.

In 2015 Russian Ministry of Health produced the first federal pilot project using the concession mechanism in the healthcare sector. Competitive industries creation, whose products will be in demand in traumatology, orthopedics, and neurosurgery, was conducted on the basis of a property object of the Novosibirsk Institute of Traumatology and Orthopedics named after Ya.L. Tsivyan [6].

In the Volgograd region, the implementation of measures on public-private partnerships development in the healthcare sector is carried out in the framework of the regional state program "Health Development of Volgograd region until 2020". The program is approved by the Volgograd region Government decree dated April 30, 2013, number 216-p "On approval of the Volgograd Region Health Care Development Program until 2020" [7].

The public-private partnership development is conducted in the form of concessions. In particular, due to the mechanism of public-private partnership, there has been a hemodialysis center established in Volgograd. The amount of private investment for the project was more than 350 million rubles.

In June 2016 the "Elton" resort was concessioned in the framework of a public-private partnership in the Pallasovsky municipal district. The investor, who has won a tender for the concession agreement, is building a dormitory for 270 seats, baths, a swimming pool. The project investment cost is 850 million rubles. The object will provide quality service, available to the entire population.

There is a widespread practice of using contract forms of quasi-public-private partnerships in the form of writing contracts to perform support functions for the medical organization by the private sector (outsourcing).

In the Volgograd region it is primarily a transport service. Two-thirds of the available health facilities' vehicles 
are completely worn out. It is not possible to acquire new ambulances within a budget or fund of obligatory medical insurance. Under the contracts, purchasing transport services from specialized companies upgraded the transport fleet.

The new vans are targeted at medical and general paramedical teams and equipped with all necessary medical equipment, the cost of which is about $70 \%$ of the value of the car. Under the contract, Volgograd received new cars in the second quarter of 2016, however, the state will be paying for the services in the next five years.

In the regional medical institutions the outsourcing of catering and cleaning services is actively developing. The regional clinical hospital №1 became a pilot project. Outsourcing of catering services has allowed the regional hospital to save funds spent on maintenance of own catering and laundry facilities. The food quality has increased significantly, which patients highly appreciated. In 2016, 39 out of 68 regional 24-hour-treatment hospitals switched to outsourcing catering [8].

Benefits from the transfer of non-core functions to the medical institution are the following: significant decrease of the staff workload, better management of the cost of their own hardware and software purchase, support, maintenance, and replacement. In the end, the client gets rid of a number of unsolvable in the current budgetary environment problems. At the same time, the most important task in the current phase of transition to the new scheme of relations will be forming a trusting and responsible relationship with the contractor, providing outsourcing services.

By focusing on providing medical services itself, health care representatives use an outsourcing scheme in all non-core processes, such as: medical equipment maintenance; laboratory testing; garbage and anatomical waste removal; access control, security and maintenance of public order in the hospital area; catering equipment maintenance, elevators, water supply, sanitation, laundry; prepared meals supply, etc. However, it should be noted that in many cases traditional activities in the healthcare sector, in which there is a little use of the potential of PPPs, are elected. For example, little attention is paid to the personnel training in working with novel technology in terms of new standards and practices, as well as to various medical equipment and information systems technical support, etc.

The search for new forms and possibilities of interaction between government and business continues. There are legal conditions created for a life cycle contract conclusion to perform work on the design and construction of facilities in the healthcare sector, as well as investment contracts in respect of the federal health care infrastructure. Care

In Russia PPP is not developing as fast as in foreign countries, this can be explained with subjective factors, such as the low level of legal and economic competence of authorities, lobbying of individual groups' interests, the weakness of civil society institutions. There are also objective reasons, including lack of Russian state property management model.

Through legislation and other legal provisions, the state should, as is done in other countries, clearly identify the boundaries of its responsibility towards society for the available property and determine on the level of federal law the range of objects not subject to privatization. In this regard, legal uncertainty contributes to corruption and leads to a private monopoly in place of a state monopoly with all the negative consequences for the state and society.

Available potential of public-private partnership in the healthcare sector has not been fully utilized. One of the main reasons for this is the lack of formed management system in the development of the institution at both the federal and regional levels. The Strategy of the subjects of the Russian Federation and municipal entities does not currently include practical experience in operating projects based on publicprivate partnership, namely, the principles and mechanisms of interaction between government and business, targeted management program in financing and implementation of public-private partnership projects. Foreign as well as the other regions experience should be formalized in strategic documents, which have to include a set of forms, methods, and tools of partnership projects management in the healthcare sector. Development and implementation of such a mechanism will create objective conditions to minimize risks and to facilitate the private investment flow into the sector.

It should be noted that a business, entering partnership projects in health care, is interested in long-term and stable cooperation, i.e. when "rules of the game" are clear and known in advance guaranteeing invested capital recovery and a required rate of return. Authorities need to hold an open dialogue with the business the following way:

find mechanisms to stimulate and promote social responsibility;

clearly define the powers of the authorities who are responsible at all preparation and implementation stages of joint projects at the regional and local levels;

create projects database that can be implemented on the basis of PPPs;

monitor the joint projects implementation effectiveness;

provide media coverage of positive PPPs experience (which in turn can attract investors);

organize a systematic approach to training specialists in order to form teams for the effective PPP projects implementation.

Furthermore, due to the direct social orientation of this sector of the economy, a lack of market mechanisms development, and a great scale of the accumulated problems of the industry, as well as a budget and resources deficit of economic entities, it is necessary to gain active government support of partner relations between authorities and business.

Public-private partnership agreements implementation, complicated by prolonged approval procedures, long-term 
nature of such projects, a high level of risk, and often their unpredictable nature, requires a certain professional level of project financing skills, which the majority of authority representatives are missing.

In this context, the task of organizing qualified PPP projects support at all stages of their life cycle becomes relevant. It is advisable to entrust the functions of information, consulting, organizational and methodological partnership projects support to the Development Corporations acting as a non-profit organization at the level of subjects of the Russian Federation [9].

Thus, the most important PPPs development strategy in health care is a successful adaptation of foreign and domestic PPPs experience to the Russian reality, which implies the need to create enabling legal, organizational and institutional conditions.

It requires the following:

- the legal framework development, adoption of a number of regulations governing partnerships between the state and business;

- creation of partnership development programs, comprehensive private investor support instruments, conditions for financial resources attraction for the joint projects implementation;

- development of practical documents and open Database projects, which will replicate the successful experience;

- creation of structures, development institutions, whose primary purpose is a full partnership projects support;

- enhancing the civil society institutions role in the partnership projects, all stakeholders' involvement in their implementation.

Only in this case, a public-private partnership will be an effective tool for healthcare modernization.

Implementation of a set of the measures above will improve the healthcare sector management efficiency, eliminate "investment drought", solve the accumulated problems through government and business partnership mechanisms development.

\section{CONCLUSION}

The following conclusions can be drawn from the analysis:

1. Effective PPP projects implementation in the healthcare sector is not possible without taking into account the factors of the institutional environment.

An objective assessment of the impact of these factors is a necessary condition for the development of an efficient organizational and economic mechanism of health PPP projects implementation. There is an urgent need to develop a strategic PPP management system due to the great social importance of the sector.
2. International practices of public-private partnerships in health care show the efficiency growth, treatment cost reduction, and the increase in public resources savings by an average of $10 \%$. Adapting international experience requires taking into account peculiarities of partnerships development at the federal level and at the level of the subjects of the Russian Federation.

Currently, in the Russian Federation, health care uses fixed assets of 2.0-2.2 trillion rubles, while the degree of the funds' wear and tear is $40-45 \%$. In order to meet the strategic objectives of modernization, the sector requires investments of about 1.0 trillion rubles. This problem can be solved by the PPPs mechanism application. However, the existing regulatory framework significantly reduces the possibility of using tools to support the private sector in the partnership projects implementation. Thus, according to Art. 100 Para. 4 of the Budget Code of the Russian Federation, local governments cannot provide municipal guarantees for a period exceeding 10 years, while, for example, concession agreements can be signed for 15-20 years. Other financial support instruments application practice (subsidizing interest rates on borrowed loans, investment tax credits, tax benefits) is not widespread and does not stimulate private investments.

We offer a strategic improvement of the PPPs organizational and economic mechanism, which will create a favorable institutional environment for the effective PPP projects management and implementation and contribute to the health infrastructure modernization, and ultimately increase the accessibility and quality of health services.

\section{References}

[1] Study on "Public-Private Partnership in Russia 2016-2018: Current State and Trends, Regions Rating."- M.; "Center for PPP development" Association, 2016. - 32 p.

[2] V.L. Adzhienko, N.N. Kosinova. Strategic Analysis of Public-Private Partnership in Health Sector / V.L. Adzhienko, N.N. Kosinova. "Pharmacy and Pharmacology". 2017. Vol. 5, no.4. - pp. 380-400.

[3] S.A.Kraevoy. Development Prospects of Public-Private Partnerships in Health Care. Medical Authorities Information Support Portal. [Electronic resource]

[4] T. Bateneva. Private Investment in Health Care will Improve its Quality and Accessibility / T. Bateneva // Russian Business Newspaper: PublicPrivate Partnership. 2012. №2.

[5] Federal Law dated 13.07.2015 № 224-FZ (edit. by 29.12.2015) "On Public-Private Partnership, Municipal-Private Partnership in Russian Federation, and Amendments to Certain Legislative Acts of Russian Federation"//ATP " Consultant Plus ".

[6] Electronic resource: http://medevent.info/upload/iblock/0db/0db04faabad05389d6b6819d528 053c4.pdf

[7] Volgograd Region Government Decree of 30.04.2013 № 216-p "Approving the Health Development Programme until 2020 in Volgograd Region» // ATP "Consultant Plus".

[8] PPP Arrangements are being Introduced in Health Care of Volgograd Region / Electronic resource: http://riac34.ru/news/62771/

[9] N.Kosinova, M. Tolstel, A. Chekealkina. Comprehensive Evaluation of Investment Potential (The Case of the Southern Federal District) / N. Kosinova, M. Tolstel, A. Chekealkina // Asian Social Science, No. 23 December 2014. P. 231-243. 